\title{
Determination of heavy metals in chinese prickly ash from different production areas using inductively coupled plasma-mass spectrometry
}

\author{
Xing-Bao Tao", Wei Peng ${ }^{1}$, Xiao-Qin $\mathrm{Yu}^{2}$, Da-Shuai $\mathrm{Xie}^{1}$, Mei-Bian $\mathrm{Hu}^{1}$, Dan \\ Yan ${ }^{1}$, Chong-Bo Zhao ${ }^{1}$, Wei-Dong Jiang ${ }^{2}$ and Chun-Jie $\mathbf{W u}^{1 *}$ \\ ${ }^{1}$ College of pharmacy, Chengdu University of Traditional Chinese Medicine, Chengdu, 611137, ${ }^{2}$ Sichuan Institute for Food and \\ Drug Control, Chengdu, 611731, China
}

*For correspondence: Email: wucjcdtcm@163.com

\begin{abstract}
Purpose: To determine the heavy metal content of Chinese prickly ash (CPA) produced in various areas of China.

Methods: CPA samples collected from different production areas in China were subjected to microwave digestion, and the contents of copper (Cu), nickel (Ni), chromium (Cr), lead (Pb), cadmium (Cd), arsenic $(\mathrm{As})$, mercury $(\mathrm{Hg})$, tin $(\mathrm{Sn})$, and antimony $(\mathrm{Sb})$ were determined by inductively coupled plasma-mass spectrometry (ICP-MS).

Results: Heavy metal levels in the CPA samples followed the order: $\mathrm{Cu}(3.29-24.17 \mathrm{mg} / \mathrm{kg})>\mathrm{Cr}(0.04-$ $7.33 \mathrm{mg} / \mathrm{kg})>\mathrm{Ni}(0.88-6.86 \mathrm{mg} / \mathrm{kg})>\mathrm{Pb}(0.00-3.84 \mathrm{mg} / \mathrm{kg})>\mathrm{As}(0.0011-1.08 \mathrm{mg} / \mathrm{kg})>\mathrm{Cd}(0.029-0.211$ $\mathrm{mg} / \mathrm{kg})>S b(0.03-0.21 \mathrm{mg} / \mathrm{kg})>\mathrm{Sn}(0.00-0.15 \mathrm{mg} / \mathrm{kg})>\mathrm{Hg}(0.000-0.032 \mathrm{mg} / \mathrm{kg})$. Metal-to-metal correlation studies showed that there were significant correlations between $\mathrm{Cu}-\mathrm{Cr}(p=-4.02), \mathrm{Cu}-\mathrm{Ni}(\mathrm{p}=$ 0.561), Cu-As $(p=0.554)$ and Ni-As $(p=0.428)$ at the 0.01 level. Also, some metal-to-metal correlations were observed in $\mathrm{Pb}-\mathrm{Cr}(p=0.351), \mathrm{Pb}-\mathrm{Cu}(p=-0.310), \mathrm{Sb}-\mathrm{Cd}(p=0.322), \mathrm{Sb}-\mathrm{Hg}(p=$ $0.311)$ and $C d-S n(p=0.309)$ at the 0.05 level. The highest concentrations of Pb and As in CPA exceeded the maximum permissible limits in China. Based on current safety standards, the concentrations of heavy metals in these CPA samples mean they are safe for human consumption.

Conclusions: The status of heavy metal concentrations of CPA should be further investigated in Sichuan, Shaanxi, Shanxi and Jiangsu. In addition, ICP-MS is a reliable and rapid technique for the determination of the heavy metals in CPA.
\end{abstract}

Keywords: Chinese prickly ash, Heavy metals, Inductively-coupled plasma-mass spectrometry, Food safety

Tropical Journal of Pharmaceutical Research is indexed by Science Citation Index (SciSearch), Scopus, International Pharmaceutical Abstract, Chemical Abstracts, Embase, Index Copernicus, EBSCO, African Index Medicus, JournalSeek, Journal Citation Reports/Science Edition, Directory of Open Access Journals (DOAJ), African Journal Online, Bioline International, Open-J-Gate and Pharmacy Abstracts

\section{INTRODUCTION}

Currently, food pollution by heavy metals has become a threat to human health because of environmental contamination, industrial waste, and fertilizers used in agriculture, as well as various anthropogenic pollutants [1]. In addition, toxic heavy metals in plants could be influenced by the geochemical constituents of soil, pollution of water and air, and the selective accumulation of some elements in plants themselves [2].

Although some metals, such as $\mathrm{Cu}, \mathrm{Ni}, \mathrm{Cr}, \mathrm{Mn}$, Mo, Zn, Fe, Co, and Al, are essential nutrients for plant growth, they can also present phytotoxic effects in human beings at concentrations 
greater than threshold concentrations [3]. It has been reported that several diseases, such as disorders of the nervous, digestive, and hematopoietic systems and even organ deformities, could be caused by heavy metal poisoning, including $\mathrm{Pb}, \mathrm{Cd}, \mathrm{As}, \mathrm{Hg}, \mathrm{Sn}$, and $\mathrm{Sb}$ poisoning $[4,5]$. Therefore, with increasing industrialization and environmental pollution, it is necessary to monitor the content of some toxic heavy metal elements in various foods.

Chinese prickly ash (CPA), including Zanthoxylum schinifolium Sieb. Et Zucc. (ZS) and $Z$. bungeanum Maxim (ZB) (Rutaceae), is a famous condiment widely used in China, and it is mainly distributed in Sichuan, Gansu, and Shaanxi [6]. Although CPA has aroused considerable attention for its chemical constituents, quality control, and possible uses, it is disappointing that systemic research regarding the heavy metal profile of this well-known food is still lacking $[7,8]$. Therefore, our present study was designed to investigate the contents of some toxic heavy metal elements, including $\mathrm{Cu}, \mathrm{Ni}, \mathrm{Cr}$, $\mathrm{Pb}, \mathrm{Cd}, \mathrm{As}, \mathrm{Hg}, \mathrm{Sn}$, and $\mathrm{Sb}$, in $\mathrm{CPA}$ from different CPA-producing areas using inductively coupled plasma mass spectrometry (ICP-MS).

\section{EXPERIMENTAL}

\section{Materials and reagents}

Forty-two CPA samples were collected from the primary of CPA-producing areas in China and were identified by Professor Min Li (College of Pharmacy, Chengdu University of TCM). $Z$. schinifolium Sieb. Et Zucc. (ZS) samples were collected from Yunnan, Chongqing, and Sichuan, and $Z$. bungeanum Maxim (ZB) samples were collected from Gansu, Shaanxi, and Sichuan etc. Concentrated nitric acid and $30 \%$ hydrogen peroxide were purchased from Kermel Chemical Reagent Co, Ltd. (Tianjin, China). Concentrated hydrochloric acid and hydrofluoric acid were purchased from Xilong Chemical Co, Ltd. (Chengdu, China). A multi-elemental mixture of metal standards was purchased from the National Testing Center of Nonferrous Metals and Electronic Materials analysis (Beijing, China). All other reagents used in our present study were of chromatographically pure grade.

\section{Sample preparation}

The collected samples were crushed over a sieve III filter, then placed in a dryer and dried before use. The testing samples $(0.3 \pm 0.0001 \mathrm{~g})$ were precisely weighed and placed in a microwave digestion tank. Next, $8 \mathrm{~mL}$ of nitric acid was added and placed in an airtight container at room temperature for $30 \mathrm{~min}$. Microwave digestion was subsequently performed. The digestion process was as follows: the temperature was increased from room temperature to $120{ }^{\circ} \mathrm{C}$ and held for $12 \mathrm{~min}$, and then the temperature was increased to 165 ${ }^{\circ} \mathrm{C}$ in $6 \mathrm{~min}$ and held for $10 \mathrm{~min}$. The temperature was then increased to $180{ }^{\circ} \mathrm{C}$ in $5 \mathrm{~min}$ and held for $25 \mathrm{~min}$. Finally, the samples were concentrated and washed for ICP-MS determination.

\section{Instruments and optimum conditions}

The ICP-MS spectrometer combined with a quadrupole analyzer and collision chamber (Agilent Technologies, USA) were used to perform the heavy metal determination. In this study, the optimal operating conditions for ICPMS analysis are shown in Table 1.

Table 1: Optimal ICP-MS operating conditions for analysis of studied samples

\begin{tabular}{ll}
\hline Instrument parameter & Condition \\
\hline RF power & $1200 \mathrm{~W}$ \\
RF frequency & $21.69 \mathrm{MHz}$ \\
RF Matching & $1.38 \mathrm{~V}$ \\
Carrier gas (inner) & $0.82 \mathrm{~L} / \mathrm{min}$ \\
Makeup Gas & $0.14 \mathrm{~L} / \mathrm{min}$ \\
Plasma gas & $\mathrm{Ar} \times 50 \mathrm{~S} 5.0$ \\
Plasma gas flow (Ar) & $13 \mathrm{~L} / \mathrm{min}$ \\
Nebulizer pump & $0.1 \mathrm{rps}$ \\
Sample untake & $0.5 \mathrm{~mL} / \mathrm{min}$ \\
Spray chamber & $3{ }^{\circ} \mathrm{C}$ \\
temperature & \\
Resolution m/z & $254 \mathrm{amu}$ \\
Background & $<5 \mathrm{cps}(9 \mathrm{amu})$ \\
Short-term stability & $<3 \%$ \\
Long-term stability & $<4 \%{ }^{60} \mathrm{Ni},{ }^{63} \mathrm{Cu},{ }^{10} \mathrm{AS}$, \\
Isotopes measured & ${ }^{111} \mathrm{Cr},{ }^{11},{ }^{118} \mathrm{Sn},{ }^{121} \mathrm{Sb}$, \\
& ${ }^{202} \mathrm{Hg},{ }^{208} \mathrm{~Pb}$ \\
\hline
\end{tabular}

\section{Method validation}

Mixed internal standard solutions with a concentration of $1,000 \mu \mathrm{g} / \mathrm{mL}$, including ${ }^{45} \mathrm{Sc}$, ${ }^{72} \mathrm{Ge}$, ${ }^{115} \mathrm{In}$, and ${ }^{209} \mathrm{Bi}$, were used to correct the changes in the sample uptake rate and plasma conditions for the ICP-MS measurements. The analytical characteristic of the proposed method was obtained for the nine elements studied under the optimized conditions. Table 2 presents the linear ranges used for calibration and the coefficients of determination ( $R$ ) used to assess the linearity $(R>0.999)$. The concentrations of $\mathrm{Pb}$ and $\mathrm{As}$ in CPA samples exceeded the maximum permissible limits in China. The limits of detection (LOD) and quantification (LOQ) for each metal were determined as follows: nine 
independent analyses of a blank solution spiked with the metal at a lower level of concentration of the analytical curve were performed. LOD and LOQ were calculated from the standard deviation $(\sigma)$ of these determinations (LOD $=3 . \sigma$ and LOQ $=10 . \sigma)$.

\section{Statistical analysis}

Statistical calculations and analysis were performed using SPSS 19.0 (SPSS Inc., USA). Difference in heavy metal concentrations among different CPA samples was detected using Pearson correlation analysis was used for data analyzing. The level of significance was taken as $p<0.05$ and $p<0.01$.

\section{RESULTS}

To obtain the reliability of the results, recoveries were calculated by spiking with aliquots of metal standards and then analyzing them as usual, according to the original concentrations of the spiked samples [9]. Acceptable recoveries of 95$100 \%$ were obtained for externally added $\mathrm{Cu}, \mathrm{Ni}$, $\mathrm{Cr}, \mathrm{Pb}, \mathrm{Cd}, \mathrm{As}, \mathrm{Hg}, \mathrm{Sn}$, and $\mathrm{Sb}$, respectively. We included at least one laboratory duplicate for each CPA sample, and the result for each batches was analyzed in three times. Moreover, Table 2 presented a good linear ranges used for calibration and the coefficients of determination.

ICP-MS results for CPA samples are listed in Table 3. The basic statistical data such as the number of samples, mean values, minimum and maximum values can be seen. Analysis of results indicate that, the highest concentration of $\mathrm{Cr}$ was found in Sichuan $(7.33 \mathrm{mg} / \mathrm{kg})$, and that of $\mathrm{Ni}$ was found in Shandong $(6.86 \mathrm{mg} / \mathrm{kg})$. Moreover, we obtained a high content of As in Sichuan $(1.08 \mathrm{mg} / \mathrm{kg})$. In the case of CPA samples, $\mathrm{Cu}$ is the most abundant metal in all CPA samples, the range of $\mathrm{Cu}$ concentration was 3.29 (in Sichuan) and $24.17 \mathrm{mg} / \mathrm{kg}$. while for As 0.0011-1.08 mg/kg (in Sichuan and Gansu, respectively), and Sb
0.03-0.21 mg/kg (for Gansu, Sichuan). Cd levels ranged from 0.029-0.21 $\mathrm{mg} / \mathrm{kg}$ (Gansu, Chongqing). Sn was the lowest concentration all analyzed heavy metals (most production areas were not detected), follow by $\mathrm{Hg}$ were not detected only in Sichuan and Shanxi. Furthermore, the highest concentration of $\mathrm{Pb}$ level was $3.84 \mathrm{mg} / \mathrm{kg}$ in Shaanxi, and the lowest was not detected in Gansu.

Correlation coefficients between metal concentrations were presented in Table 4. Statistical analysis by SPSS showed metal-tometal correlations for all samples between $\mathrm{Cu}-\mathrm{Cr}$ $(p=-4.02)$, Cu-Ni $(\mathrm{P}=0.561)$, Cu-As $(p=0.554)$ and Ni-As $(p=0.428)$ at the 0.01 level. Also, some metal-to-metal correlations were observed in $\mathrm{Pb}-\mathrm{Cr}(p=0.351), \mathrm{Pb}-\mathrm{Cu}(p=-0.310)$, Sb-Cd $(p=0.322), \mathrm{Sb}-\mathrm{Hg}(p=0.311)$ and $\mathrm{Cd}-\mathrm{Sn}(p=$ 0.309 ) at the 0.05 level. Moreover, others metalto-metal correlations for CPA samples were not significant, and each ion appeared independent.

\section{DISCUSSION}

The aim of this study was to determine the concentrations of heavy metals in CPA. We obtained results indicate that the concentration of heavy metals contamination differs significantly depending on the production area. Furthermore, the result showed that the concentrations of elements may also differ even within the same production area and the same variety, depending on climate and soil conditions where the CPA were grown.

Based our investigations, the Chinese food standards only regulated the concentrations of As, $\mathrm{Pb}, \mathrm{Cd}$ and $\mathrm{Hg}$ in CPA, which sets a limit for dried samples $(0.3 \mathrm{mg} / \mathrm{kg}$ for As, $0.50 \mathrm{mg} / \mathrm{kg}$ for $\mathrm{Cd}, 0.03 \mathrm{mg} / \mathrm{kg}$ for $\mathrm{Hg}$, and $1.86 \mathrm{mg} / \mathrm{kg}$ for $\mathrm{Pb}$ ). However, for other heavy metals we have not found any requirements.

Table 2: Linear range, regression correlation coefficient (R), LOD, LOQ

\begin{tabular}{lccccc}
\hline Element & $\begin{array}{c}\text { Linear range } \\
(\mathbf{m g} / \mathbf{k g})\end{array}$ & Regression & $\mathbf{R}^{\mathbf{2}}$ & $\begin{array}{c}\text { LOD } \\
(\mathbf{m g} / \mathbf{k g})\end{array}$ & $\mathbf{L O Q}(\mathbf{m g} / \mathbf{k g})$ \\
\hline $\mathrm{Cr}$ & $0-100$ & $\mathrm{y}=0.00027 x-1.74815$ & 0.99915 & 0.3258 & 1.0755 \\
$\mathrm{Ni}$ & $0-100$ & $\mathrm{y}=0.00022 x-0.48819$ & 0.99997 & 0.3452 & 1.1392 \\
$\mathrm{Cu}$ & $0-100$ & $\mathrm{y}=0.00011 x-2.19595$ & 0.99996 & 0.6794 & 2.2421 \\
$\mathrm{As}$ & $0-100$ & $\mathrm{y}=0.00048 x-0.78168$ & 0.99996 & 0.00011 & 0.00037 \\
$\mathrm{Cd}$ & $0-100$ & $\mathrm{y}=0.00025 x+0.22823$ & 0.99998 & 0.0184 & 0.0599 \\
$\mathrm{Sn}$ & $0-100$ & $\mathrm{y}=0.00007 x-0.36808$ & 0.99999 & 0.0132 & 0.0433 \\
$\mathrm{Sb}$ & $0-100$ & $\mathrm{y}=0.00008 x+0.10945$ & 0.99998 & 0.028 & 0.0932 \\
$\mathrm{Hg}$ & $0-100$ & $\mathrm{y}=0.00028 x+0.11307$ & 0.99985 & 0.0081 & 0.0267 \\
$\mathrm{~Pb}$ & $0-100$ & $\mathrm{y}=0.00003 x-1.14500$ & 0.99999 & 0.0935 & 0.3009 \\
\hline
\end{tabular}


Table 3: Concentrations of heavy metals in different production areas of CPA $(\mathrm{mg} / \mathrm{kg})$

\begin{tabular}{|c|c|c|c|c|c|c|c|c|c|c|c|}
\hline \multirow{2}{*}{$\begin{array}{l}\text { Production } \\
\text { area }\end{array}$} & \multirow[t]{2}{*}{$\mathbf{N}$} & \multicolumn{10}{|c|}{ Analyzed Metals (mg/kg) } \\
\hline & & Statistics & $\mathbf{C r}$ & $\mathbf{N i}$ & $\mathrm{Cu}$ & As & $\mathrm{Sb}$ & Cd & Sn & $\mathrm{Hg}$ & $\mathbf{P b}$ \\
\hline \multirow[t]{4}{*}{ Gansu } & 13 & Mean & 1.84 & 1.85 & 6.59 & 0.05 & 0.075 & 0.039 & & 0.016 & \\
\hline & & Min. & 0.08 & 1.29 & 4.06 & 0.0011 & 0.03 & 0.029 & ND & 0.011 & ND \\
\hline & & Max. & 3.21 & 3.57 & 8.19 & 0.12 & 0.15 & 0.06 & 0.02 & 0.023 & 1.25 \\
\hline & & SD & 0.02 & 0.05 & 0.06 & 0.0168 & 0.006 & 0.003 & & 0.0002 & \\
\hline \multirow[t]{4}{*}{ Sichuan } & 10 & mean & 2.14 & 2.71 & 5.83 & 0.18 & 0.09 & 0.10 & & & 0.86 \\
\hline & & Min. & 0.14 & 1.59 & 3.29 & 0.004 & 0.01 & 0.03 & ND & ND & 0.2 \\
\hline & & Max. & 7.33 & 5.88 & 13.2 & 1.08 & 0.21 & 0.18 & 0.15 & 0.032 & 3.12 \\
\hline & & SD & 0.02 & 0.05 & 0.05 & 0.02 & 0.02 & 0.02 & & & 0.05 \\
\hline \multirow[t]{4}{*}{ Shaanxi } & 6 & Mean & 1.52 & 1.93 & 8.77 & 0.105 & 0.063 & 0.07 & 0.055 & 0.022 & 1.63 \\
\hline & & Min. & 0.04 & 1.12 & 4.69 & 0.02 & 0.02 & 0.05 & 0.03 & 0.02 & 0.01 \\
\hline & & Max. & 2.89 & 2.96 & 13.5 & 0.27 & 0.09 & 0.10 & 0.08 & 0.024 & 3.84 \\
\hline & & SD & 0.02 & 0.04 & 0.05 & 0.014 & 0.013 & 0.011 & 0.002 & 0.0005 & 0.03 \\
\hline \multirow[t]{4}{*}{ Chongqing } & 2 & Mean & 1.055 & 3.54 & 5.36 & 0.07 & 0.20 & 0.16 & & 0.0225 & 0.94 \\
\hline & & Min. & 0.73 & 2.45 & 5.33 & 0.002 & 0.19 & 0.11 & ND & 0.021 & 0.43 \\
\hline & & Max. & 1.38 & 4.63 & 5.39 & 0.14 & 0.20 & 0.211 & ND & 0.022 & 1.44 \\
\hline & & SD & 0.025 & 0.02 & 0.06 & 0.016 & 0.035 & 0.03 & & 0.0003 & 0.065 \\
\hline \multirow[t]{4}{*}{ Jiangsu } & 2 & Mean & 2.17 & 2.96 & 10.8 & 0.081 & 0.07 & 0.065 & & 0.021 & 1.07 \\
\hline & & Min. & 0.16 & 1.66 & 4.88 & 0.064 & 0.06 & 0.06 & ND & 0.020 & 0.02 \\
\hline & & Max. & 4.17 & 4.25 & 16.8 & 0.099 & 0.08 & 0.07 & 0.06 & 0.023 & 2.12 \\
\hline & & SD & 0.02 & 0.10 & 0.07 & 0.06 & 0.025 & 0.007 & & 0.0009 & 0.045 \\
\hline \multirow[t]{4}{*}{ Shanxi } & 4 & Mean & 0.995 & 1.68 & 11.10 & 0.09 & 0.078 & 0.065 & & & 0.95 \\
\hline & & Min. & 0.14 & 0.88 & 4.25 & 0.07 & 0.07 & 0.05 & ND & ND & 0.01 \\
\hline & & Max. & 1.94 & 3.88 & 14.5 & 0.11 & 0.08 & 0.08 & 0.04 & 0.041 & 2.12 \\
\hline & & SD & 0.02 & 0.04 & 0.10 & 0.04 & 0.003 & 0.006 & & & 0.03 \\
\hline \multirow[t]{4}{*}{ Shandong } & 2 & Mean & 0.95 & 4.28 & 14.4 & 0.068 & 0.06 & 0.055 & & 0.0215 & 1.27 \\
\hline & & Min. & 0.14 & 1.67 & 4.65 & 0.063 & 0.06 & 0.05 & ND & 0.021 & 1.14 \\
\hline & & Max. & 1.76 & 6.86 & 24.17 & 0.072 & 0.06 & 0.06 & ND & 0.022 & 1.4 \\
\hline & & SD & 0.01 & 0.09 & 0.15 & 0.003 & 0.05 & 0.001 & & 0.0008 & 0.035 \\
\hline \multirow{4}{*}{ Guizhou } & 2 & Mean & 1.02 & 2.95 & 13.40 & 0.31 & 0.06 & 0.055 & & 0.0235 & 0.43 \\
\hline & & Min. & 0.35 & 1.60 & 6.75 & 0.063 & 0.05 & 0.05 & ND & 0.023 & 0.02 \\
\hline & & Max. & 1.69 & 4.29 & 19.96 & 0.084 & 0.07 & 0.06 & 0.04 & 0.024 & 0.83 \\
\hline & & SD & 0.01 & 0.04 & 0.05 & 0.074 & 0.03 & 0.02 & & 0.009 & 0.03 \\
\hline \multirow[t]{3}{*}{ Yunnan } & 1 & Mean & 4.32 & 1.84 & 4.70 & 0.05 & 0.06 & 0.10 & & 0.025 & 1.13 \\
\hline & & Min. & 4.32 & 1.84 & 4.70 & 0.05 & 0.06 & 0.10 & ND & 0.025 & 1.13 \\
\hline & & $\begin{array}{l}\text { Max. } \\
\text { SD }\end{array}$ & 4.32 & 1.84 & 4.70 & 0.05 & 0.06 & 0.10 & ND & 0.025 & 1.13 \\
\hline \multirow[t]{4}{*}{ All samples } & & Mean & 1.76 & 2.38 & 7.95 & 0.897 & 0.088 & 0.063 & & & \\
\hline & & Min. & 0.04 & 0.88 & 3.29 & 0.0011 & 0.03 & 0.029 & ND & ND & ND \\
\hline & & Max & 7.33 & 6.86 & 24.17 & 1.08 & 0.21 & 0.211 & 0.15 & 0.032 & 3.84 \\
\hline & & SD & 0.02 & 0.05 & 0.074 & 0.03 & 0.018 & 0.022 & & & \\
\hline
\end{tabular}

Note: $N D=$ not detected

Table 4: Correlation coefficients between metal concentrations

\begin{tabular}{|c|c|c|c|c|c|c|c|c|c|}
\hline & $\mathrm{Cr}$ & $\mathrm{Ni}$ & $\mathrm{Cu}$ & As & $\mathrm{Sb}$ & Cd & Sn & $\mathrm{Hg}$ & $\mathbf{P b}$ \\
\hline $\mathrm{Cr}$ & 1.000 & -0.153 & -4.200 & -0.126 & -0.071 & -0.104 & -0.126 & 0.062 & 0.351 \\
\hline $\mathrm{Ni}$ & & 1.000 & $0.561^{\wedge}$ & $0.428^{n}$ & 0.185 & 0.175 & 0.096 & 0.186 & -0.029 \\
\hline $\mathrm{Cu}$ & & & 1.000 & $0.554^{n}$ & -0.302 & 0.004 & 0.117 & -0.028 & -0.310 \\
\hline As & & & & 1.000 & -0.113 & 0.037 & 0.144 & 0.119 & -0.070 \\
\hline $\mathrm{Sb}$ & & & & & 1.000 & $0.322^{\pi}$ & -0.202 & $0.311^{\star}$ & 0.063 \\
\hline $\mathrm{Cd}$ & & & & & & 1.000 & $0.309^{\prime}$ & -0.084 & 0.099 \\
\hline $\mathrm{Sn}$ & & & & & & & 1.000 & -0.260 & -0.245 \\
\hline $\mathrm{Hg}$ & & & & & & & & 1.000 & 0.261 \\
\hline $\mathrm{Pb}$ & & & & & & & & & 1.000 \\
\hline
\end{tabular}

${ }^{*}$ Correlation is significant $95 \% \mathrm{Cl} ;{ }^{* *}$ Correlation is significant at $99 \% \mathrm{Cl}$

Our studies have demonstrated that the content of heavy metals do not exceed the maximum permissible limits in CPA samples according to Chinese food standards, except for $\mathrm{Pb}$ and As. Meanwhile, a summary on maximum values for heavy metals set by countries in different regions of the world has been recently published by the WHO in 2007 [10], which proposes a limit of 10 $\mathrm{mg} / \mathrm{kg}$ for $\mathrm{Pb}$ and $0.3 \mathrm{mg} / \mathrm{kg}$ for $\mathrm{Cd}$ in dried herbs. In this research, the highest 
concentrations of $\mathrm{Pb}, \mathrm{Cd}$ were $3.84 \mathrm{mg} / \mathrm{kg}, 0.211$ $\mathrm{mg} / \mathrm{kg}$ in the CPA samples from Shaanxi, Chongqing, respectively, and do not exceed the standard level of $10 \mathrm{mg} / \mathrm{kg}, 0.3 \mathrm{mg} / \mathrm{kg}$. However, the highest level of $\mathrm{Pb}$ was over the upper limits imposed $(1.86 \mathrm{mg} / \mathrm{kg})$ for Chinese food standards in Sichuan (3.12 mg/kg), Shaanxi $(3.84 \mathrm{mg} / \mathrm{kg})$, Shanxi $(2.12 \mathrm{mg} / \mathrm{kg})$ and Jiangsu $(2.12 \mathrm{mg} / \mathrm{kg})$. This may be caused by various reasons, such as air, soil pollution, etc. Also, $\mathrm{Pb}$ has no beneficial role in human metabolism and can cause some health disorders. Thus, it must be considered seriously. In addition, the result of analysis showed that the content of As (1.08 $\mathrm{mg} / \mathrm{kg}$ ) in Sichuan exceeded the maximum permissible limits in China food standards. For this reason, may be caused by soil enrichment and pesticide pollution.

According to the World Health Organization (WHO) and Food and Agriculture Organization (FAO), regarding health risks, the intake of $\mathrm{Pb}$ compounds will cause acute poisoning in humans, and metallic $\mathrm{Pb}$ is possibly carcinogenic [11]. The provisional tolerable weekly intake (PTWI) for $\mathrm{Pb}$, set as a limit for metal intake based on body weight for an average adult (60 $\mathrm{kg}$ body weight) is $1.5 \mathrm{mg}$. The researchers reported that $\mathrm{Pb}$ intake through food and drinking water was about $0.3 \mathrm{mg}$ (Europe) and $0.61 \mathrm{mg}$ (China) in every week $[12,13]$. Then, the per capita annual consumption of CPA was calculated is $0.5 \mathrm{~kg}$. Based on the Chinese food standards, when the concentration of $\mathrm{Pb}$ reached the limit requirement $(1.86 \mathrm{mg} / \mathrm{kg})$, the consumption of $\mathrm{Pb}$ is about $0.017 \mathrm{mg}$, only accounting for $1.192 \%$ in PTWI. The present study showed that the per capita annual consumption of CPA was similar to the values observed in Shaanxi, China [13]. Thus, based on current safety standards, the concentrations of heavy metals in these CPA samples mean they are safe for human consumption.

In recent years, environmental pollution constantly aggravates the constant improvement in the economic level and ecological environment destruction. Consequently, food safety problems, including heavy metal pollution, microorganisms causing foodborne diseases, pesticide residues, organic pollutants, and chemical pollution, have been reported frequently at home and abroad, and have become serious threats to human life [14]. Additionally, more and more investigations have demonstrated that heavy metals are the key factor in food pollution due to their harmful effects on human health at low concentrations.

Heavy metals that enter the body through food, interfere with normal physiological function, and harm human body health are known as toxic heavy metals. These heavy metal elements, including $\mathrm{Hg}, \mathrm{Cd}, \mathrm{Cr}, \mathrm{Pb}, \mathrm{As}$, and $\mathrm{Sn}$, which are grouped into medium toxicity $(\mathrm{Cu}, \mathrm{Sn}$, etc.) and strong toxicity elements (e.g., $\mathrm{Hg}, \mathrm{As}, \mathrm{Cd}, \mathrm{Pb}$, and $\mathrm{Cr}$ ) depend on the harm of heavy metal elements on human [15]. The contamination and enrichment of heavy metal elements may occur during production, processing, storage and transportation of food. Recently, heavy metal pollution has become the focus of much international attention, primarily because of the voluminous discharge into the environment from industrial activities. Heavy metals are toxic to ecosystems as well as humans, so their bioaccumulation in the food chain causes serious disorders [16-18]. The elements ( $\mathrm{Pb}, \mathrm{Hg}, \mathrm{Gr}, \mathrm{As}$, and $\mathrm{Cd}$ ) have significant poisonous activities against humans and cannot be degraded in the body. In addition, these heavy metals could present violent toxicities combined with other toxins in the human body. Commonly, $\mathrm{Pb}, \mathrm{As}$, and $\mathrm{Hg}$ are considered highly toxic elements that can cause serious harm to people's health and are involved in brain cell damage and hypothermia, leading to dementia, brain death, neurological disorders, and even cancer $[19,20]$.

\section{CONCLUSION}

The findings of this study indicate that $\mathrm{Cu}, \mathrm{Ni}, \mathrm{Cr}$, $\mathrm{Pb}, \mathrm{Cd}, \mathrm{As}, \mathrm{Hg}, \mathrm{Sn}$, and $\mathrm{Sb}$ are the characteristic heavy metal elements found in prickly ash, this is worth-noting in the safety monitoring of this famous Chinese famous condiment. The concentrations of $\mathrm{Pb}$ and $\mathrm{As}$ in CPA exceeded the maximum permissible limits in Sichuan, Shaanxi, Shanxi and Jiangsu. Thus, the status of heavy metal concentrations of CPA should be further investigated in Sichuan, Shaanxi, Shanxi and Jiangsu. In addition, ICP-MS is a reliable and rapid technique for the determination of the heavy metals in CPA. Based on the obtained data and current safety standards, CPA in this study are safe for human consumption.

\section{DECLARATIONS}

\section{Acknowledgement}

This work was supported by Provincial Horizontal Issues, "Chinese Hanyuan Prickly Ash Deep Processing of Key Generic Technologies and Industrialization" (Project SEQ ID no: 2014PT048).

\section{Conflict of Interest}

No conflict of interest associated with this work. 


\section{Contribution of Authors}

The authors declare that this work was done by the authors named in this article and all liabilities pertaining to claims relating to the content of this article will be borne by them.

\section{REFERENCES}

1. Leung AOW, Duzgoren-Aydin NS, Cheung KC, Ming HW. Heavy metals concentrations of surface dust from ewaste recycling and its human health implications in southeast China. Environ Sci Tech 2008; 42: 26742680.

2. Leyval C, Turnau K, Haselwandter K. Effect of heavy metal pollution on mycorrhizal colonization and function: physiological, ecological and applied aspects. Mycorrhiza 1997; 7: 139-153.

3. Shubina NA, Kolesov GM. Determination of heavy metals as environmental pollutants: use of instrumental neutron activation analysis. J Chem 2002; 57: 912-917.

4. Gupta S, Pandotra P, Gupta AP, Dhar JK, Sharma G. Volatile (As and $\mathrm{Hg}$ ) and non-volatile ( $\mathrm{Pb}$ and $\mathrm{Cd}$ ) toxic heavy metals analysis in rhizome of Zingiber of cinale collected from different locations of North Western Himalayas by Atomic Absorption Spectroscopy. Food Chem Toxicol 2010; 48: 2966-2971.

5. Madrid L, Díaz-Barrientos E, Madrid F. Distribution of heavy metal contents of urbans oils in parks of Seville. Chemosphere, 2002; 49: 1301-1308.

6. Zhao ZHF, Zhu RX, Zhong $K$, He Q, Luo AM, Gao $H$. Characterization and comparison of the pungent components in commercial Zanthoxylum bungeanum oil and Zanthoxylum schinifolium oil. Food chem 2013; 78. C1516-C1516.

7. Bora T, Aksoy Ç, Tunay Z, Aydın F. Determination of trace elements in illicit spice samples by using ICP-MS. Microchem J 2015; 123: 179-184.

8. Filipiak-Szok, Kurzawa M, Szłyk E. Determination of toxic metals by ICP-MS in Asiatic and European medicinal plants and dietary supplements. J Trace Element Med Biol 2015; 30: 54-58.

9. Han WY, Han GZH, CXX. The content status of $P b$ in tea and its research progress of control technology. China tea (China) 2008; 30(3): 16-17.

10. SAC (Standardization Administration of the People's Republic of China). Prickly ash (GB/T 30391-2013). Beijing: Chinese Standard Publishing House (China).

11. Cao $X Z$, Zeng J. The lead pollution condition in food in our country and its harm. J Pub Health Prev Med Dec (China) 2014; 25(6): 77-79.

12. Han $W Y$, Han GZH, CXX. The content status of $P b$ in tea and its research progress of control technology. China tea (China) 2008; 30(3): 16-17.

13. Zheng YN, Fan MT Guo SN. Liu J, Fang JF, Dong Q. Determination of toxic and essential metal element contents in Chinese prickly ash of Shaanxi. China condiment (China) 2012; 37(12): 88-91.

14. Al-Waili N, Salom K, Ahmed AG, Mohammad Javed A. Antibiotic, pesticide, and microbial contaminants of honey: human health hazards. Sci World J 2012; 2012: 1-7.

15. Nardi EP, Evangelist FS, Tormen L, Saint Pierre TD, Curtius A J, De Souza SS, Jr FB. The use of inductively coupled plasma mass spectrometry (ICP-MS) for the determination of toxic and essential elements in different types of food samples. Food chem 2009; 112: 727-732.

16. Gotoh T, Matsushima K, Kikuch KI. Adsorption of $\mathrm{Cu}$ and $\mathrm{Mn}$ on covalently cross-linked alginate gel beads. Chemosphere 2004; 55: 57-64.

17. Bailey SE, Olin TJ, Bricka RM, Adrian DD. A review of potentially low cost sorbents for heavy metals. Wat Res 1999; 33: 2469-2479.

18. Gilles DG, Loehr RC, ASCE F. Waste generation and minimization in the semiconductor industry. J Environ Eng 1994; 120: 72-86.

19. $Y u Y Q$, Zhang $X Z$, Liu J. The harm of heavy metal pollution on the human body. Technical thesis (China) 2008; 1: 15-16.

20. Wang $Y$. Introduction to heavy metals in food to human body harm and prevention. Qinghai Agro-tech Ext (China) 2010; 4: 8-16. 